\title{
Effects of sports personalities in marketing communication on the purchasing preferences of Generation $Y$
}

\author{
Josef Voráček* Eva Čáslavová
}

Department of Sport Management, Faculty of Physical Education and Sports, Charles University, Prague, Czech Republic

* Corresponding author: voracek@ftvs.cuni.cz

\begin{abstract}
This research determines what effect if any the use of sports celebrities in companies' marketing communications has on the purchasing preferences of Generation Y. The survey is based on the original American version from authors Bush, Martin, Bush (2004). The questionnaire-based survey involves 416 respondents who study at Prague secondary schools and universities. Group discussions with four groups comprising a total of 41 respondents are also used. The results of the research show that the use of sports celebrities in marketing communication for generation $Y$ does not have a proven effect on positive word of mouth or on switching and complaint behavior. This communication tool may have an indirect positive effect in the form of an increase in the brand/product awareness, attractiveness of a communication message and thereby increased options and tendency to try a product and a first purchase, even despite higher prices than the competition.
\end{abstract}

\section{KEYWORDS}

Sports celebrity; Generation Y; buying preferences; marketing communication; brand

DOI

10.14712/23366052.2019.10

(c) 2019 The Authors. This is an open-access article distributed under the terms of the Creative Commons Attribution License (http://creativecommons.org/licenses/by/4.0), which permits unrestricted use, distribution, and reproduction in any medium, provided the original author and source are credited. 


\section{INTRODUCTION AND THEORETICAL BACKGROUND}

The combination of famous sport celebrities and a company's brand or product is now already considered a traditional communication tool, which companies use to achieve various marketing, sales and communication objectives. These objectives may include increasing the volume of product sales as well as changes or boosting and building of the image of a brand, company and product. There may be many objectives in marketing communication, and therefore the selection of a sports celebrity attracts significant attention. Since the use of a sports celebrity is a costly item in the budget for marketing communication, the selection of an optimal sports celebrity is a demanding process. The effect and impact of such sports celebrity can then be seen in the perceived quality of the particular product, the transfer of the sports celebrity's reputation to the particular brand or a general increase in competitive advantages compared to other brands in the industry. Therefore, it depends on the subjectively perceived benefits for consumers.

The final consumer, like in overall marketing, is the reason for using sports celebrities in marketing communication. Men and women are constantly compared with the so-called reference groups, such as family, work colleagues, classmates, male and female friends as well as successful people in the surroundings, celebrities in culture and in sports, politicians, etc. Through constant comparison and an attempt to get close to these perceived ideals, consumers adapt their preferences and behavior during selection and purchasing of products of specific brands. In this manner, consumers attempt to be members of such a reference group, to belong to a certain social group, which the particular celebrity is also in. Purchasing behavior and preferences of consumers, however, are a complicated process, which is dependent on many factors. This process aims with the use of sports celebrities to influence certain brands more or less and to get a sports celebrity close to its customers, at least through its products. Of course, this influence will be different for each customer and consumer, strong for some and none for others.

One interesting group of consumers is that of young people who grew up during numerous marketing campaigns, particularly in the form of communication and advertising messages of various types. These ranged from television advertising to various forms of outdoor advertising to omnipresent marketing communication via the Internet. This group is currently entering an economically productive age, and it is one of the main groups targeted by companies. This group, or generation of consumers, otherwise referred to as "Generation Y", consists of individuals born in the 1980s and 1990s. Those were the periods when information and communication technology, with which we are familiar today, began fully developing. Generation Y learned how to use these technologies to a full extent and made them an essential part of their lives. Thanks to the omnipresent communication media, this generation of consumers instantly knows what kinds of golf clubs Tiger Wood uses, in what spikes Usain Bolt achieved a world record in running, what shoes Lionel Messi plays in, what skis Aksel Lund Svindal uses in competitions, as well as non-sports products, such as what kind of hair gel David Beckham uses for his fashionable hair styles, what watch Lewis Hamilton wears, what tattoos Mike Tyson has and a lot of other information about sports 
celebrities all over the world. All of these examples can influence what consumers buy, to be at least a bit like their favorite athletes.

The influence of reference groups to which sports celebrities belong is an integral part of all basic and new models of purchasing behavior of a consumer (McCarthy, Perreault, 1993; Koudelka, 1997; Erasmus, Boshoff, Rousseau, 2001; Jacoby, 2002; Shiffman, Kanuk, 2004; Tomek, Vávrová, 2008; Darley, Blankson, Luethge, 2010; Vysekalová et al., 2011; Martin, Morich, 2011). Reference groups are one of the effects that more or less influence the behavior of consumers, as is shown by the models of consumer behavior.

The effect of a reference group on consumer behavior can vary. Some authors (Schiffman, Kanuk, 2004; Stafford, 1966) specify two types of influences - normative (influence on behavior) and comparative (level of aspiration). However, currently many authors (Koudelka, 2006; Kotler et al., 2007; Kotler, Keller, 2007; Carmen, 2008; Escalas, Bettman, 2003; Bearden, Etzel, 1982; Chuang, Cheng, Hsu, 2012; Yang, He, Lee, 2007) specify three types of influences, which have been classified and tested with research by Park, Lessig (1977) - information based, use based and value-expressive.

For marketers, reference groups are highly beneficial tool for communicating with customers. Creative marketing communication makes it possible to combine adequate reference groups so that the target group for communication messages reacts based on defined communication objectives. Koudelka (1997) specifies three ways of using reference groups in marketing: media effects on reference groups, word-of-mouth communication and opinion leadership.

Celebrities are an integral part of today's marketing and regular life of consumers. How is this term defined, and who exactly is a celebrity? Certain definitions are presented here for clarification of the term.

Masood (2011, p. 7): "A celebrity is a person who is well known among the public and has a reputation based on professional knowledge in a selected area."

Miller, Laczniak (2011, p. 499): “Celebrities are well known individuals who receive significant attention from the media. They include actors, athletes, musicians, models and even chefs, authors, journalists and politicians. They are created, supported, promoted and sold to us via mass media."

It can be stated that a celebrity is a person who, thanks to communication via mass media, is generally known to the public or in a certain group of people. Sports celebrities used to be only sports heroes, but with gradual professionalization and media coverage of sports they have also earned the status of celebrities (Stevens, Lathrop, Bradish, 2003) and/or sports stars (Nicholson, 2007). Indeed the image of sports celebrities created by the media is considered the main difference between a sports hero and a sports celebrity. While a sports hero is known and admired thanks to real successes and sports performance, a sports celebrity is basically a creation of media presentation (Stevens, Lathrop, Bradish 2003; Nicholson, 2007).

\section{Celebrity endorsement}

Celebrity endorsement is today already a regularly used advertising technique across all industrial sectors. The comprehensive definition for marketing support using celebrities can be the following in this context: 
Celebrity endorsement is the mutual combination of a publicly known, famous and renowned individual in a certain sector and companies and/or organizations who involve such individual integrally in their marketing and especially in their communication tools.

The fact is expressed here that a combination of a company with a celebrity and/ or a sports celebrity influences not only the company's promotion policy but also the overall marketing strategy and its tactical and operative tools (product, price, distribution, marketing communication, etc.). In relation to the product itself, Lim (2005) comments that just the very essence of the combination with a celebrity is used to improve a product. In the sports sector, this applies more than usual, because athletes also receive significant attention from the media and fans, which increases their visibility and intensifies the product profile of a particular company (Schlossberg, 1996). Companies are very well aware of this fact, and they spend large amounts of money in connection with sports celebrities.

In order for companies to invest such large amounts of money into association of their brands with celebrities, including sports celebrities, it is necessary for these investments to bring about certain results. The long-term objective of various companies is, of course, financial profit, but this is achieved in various ways using various objectives. However, celebrities are not only used in marketing communication by companies but also by non-profit organizations, which have different objectives than just financial gain. The use of sports celebrities in marketing communication then forms a tool, which can fulfill various objectives and bring about various effects. The main objectives expected from the use of sports celebrities include (Martin, 1996):

- to attract the attention of consumers,

- to boost reminders of the brand name,

- to boost the image of a product,

- to increase the trustworthiness of a message,

- to increase the attractiveness of a product,

- to increase the popularity and messages of advertising,

- to increase the likelihood of a purchase.

However, the effects that have been proved, or which have appeared and been discovered, include financial and economic effects (Agrawal, Kamakura, 1995; Lear, Runyan, Whitaker, 2009; Elberse, Verleun, 2012; Clark, Horstmann, 2013), effects connected with the brand image (Lagae, 2005; Choi, Rifon, 2007; Seno, Lukas, 2007; Carroll, 2009; Simmers, Damron-Martinez, Haytko, 2009; Ranjbarian, Shekarchizade, Momeni, 2010; Temporal, 2010; Spry, Pappu, Cornwell, 2011; Keel, Nataraajan, 2012; Bhatt, Jayswal, Patel, 2013; Chan, Ng, Luk, 2013; Č́slavová, Višněvský, 2016), and effects related to purchasing behavior of the consumer.

Even despite the specified financial and economic effects and the effects connected with the image of the brand, the most important from the point of view of companies remains the actual purchasing behavior of customers and/or consumers. They namely generate revenue for companies, which leads to profit as the main objective of all companies.

Bush, Martin, Bush (2004) revealed through their research that the use of sports celebrities positively influences adolescents in their communication with peers, or the so-called W-O-M (word-of-mouth) communication and, further, their loyalty to 
a supported brand. The use of such celebrities is important when a consumer is selecting a brand of product that the consumer wishes to buy and when a consumer talks about it with other people. The same research was repeated by Dix, Phau, Pougnet (2010), and they arrived at the same conclusions and even discovered an influence on alternating of brands and products depending on the used sports celebrity, which was not confirmed in previous research. Shuart (2007) also pointed out the positive influence of using sports celebrities, particularly in this case a sports hero, on the purchasing aims of consumers.

However, Alnawas (2010) in his study denies the fundamental influence of celebrities on purchasing behavior or on the aims of consumers when selecting and purchasing products. He adds also that much greater influence comes from tools to support sales, such as discounts, coupons, events, etc. Nonetheless, the study has shown a partial influence when a supported product is used by one or more celebrities themselves as part of their work, activities and careers, or if a brand or product relates to an environment in which a particular celebrity is known and excels. This is referred to as the so-called match-up effect, or the celebrity-product congruence. However, even this effect cannot be clearly confirmed in the sports environment, as is indicated by Koernig, Boyd (2009). Their research has shown that there is no difference between the effectiveness of use of a sports celebrity for a sports brand or a non-sport brand. Moreover, they also confirm that the use of a celebrity does not have a major influence on purchasing behavior. This results in a rather more positive and increasing awareness and value of the brand of the sports celebrity.

Sliburyte (2009) states that the purchasing aims are integrally connected with the trustworthiness of a celebrity used in marketing communication through the perception of their expertise, attractiveness and popularity, in the same way as with the match-up effect. However, the previously specified research studies do not support this claim. According to Lafferty, Goldsmith (1999), the trustworthiness of a celebrity also does not have a significant influence on the purchasing intentions of consumers. On the contrary, they claim that the characteristics of the product are what matter in the end.

Pringle (2004), unlike in all of the specified research studies, specifies a whole range of case studies of advertising campaigns in which a celebrity has been used for marketing support, which have resulted in smaller or higher growth of sales, revenue, market share, profit, etc. These studies are supported by the financial results of individual companies. It can be deduced from this that although respondents in many research studies deny the influence of celebrities on their purchasing behavior, the opposite is true. Kaser, Oelkers (2005) add that many practical case studies have shown that consumers prefer more often to buy a product that is supported by a celebrity. This may also be the result of the fact that marketing support by sports celebrities influences the desire to try a particular product or brand (Chan, $\mathrm{Ng}$, Luk, 2013).

These studied effects (whether or not confirmed by research) depend, however, on other aspects of the use of sports celebrities as specified by Simmers, Damron-Martinez, Haytko (2009). These authors prepared “The Endorser Sexpertise Continuum" when certain characteristics for the use of celebrities in marketing communication apply for individual sides of the continuum in relation to purchasing behavior of a consumer. 
On one side of the continuum, the consumer is more involved and engaged in product purchasing, interested in its specified attributes and functional properties, and then acquires and uses information gradually "piece by piece". Therefore, it is desirable here to use sports celebrities due to their professionalism and trustworthiness in view of the supported product, which relates to the professionalism of the particular sports celebrity. On the other side of the continuum, the consumer is much less involved in the purchasing of products and perceives it in its wholeness and integrity. The customer is interested in the symbolic properties of the product and selects the product rather emotionally. In this case, it is not important whether or not the product relates to the sports celebrity's professionalism but the attractiveness of the sports celebrity matters more.

As the authors have already mentioned in the introduction, the work and overall research is focused on the young generation of consumers, which in current marketing is referred to as Generation $Y$. This label stems from the generational typology of consumers where the affiliation to a generation of people born in a certain time period is the main segmentation criteria.

Generation $\mathrm{Y}$ is a target group with huge economic potential. Nowadays, companies spend large amounts of money on marketing support involving celebrities. The mutual interconnection of these factors leads to the question of whether the use of celebrities in marketing communication aimed at Generation Y has an effect. Morton (2002) states that celebrities and sports celebrities have the greatest effect on Generation $Y$, and their impact is even greater than advertising. However, it remains questionable when a celebrity is used in advertising. Van Den Bergh, Behrer (2012) describe this strategy as problematic, since young people are very critical of it. They state literally:

From their point of view, support from a celebrity means that the brand does not have enough awareness to have its own images, and they interpret this as a weakness of the brand. This shows that the brand does not have an actual personality, and it must buy a cool image for itself using cool persons. Therefore, celebrity endorsement pays off only under certain circumstances, such as when the segment of a product is associated with the natural environment and skills of a particular celebrity. When sports celebrities like Michael Jordan and Tiger Woods are the actual faces of the Nike brand. (Van Den Bergh, Behrer, 2012, p. 124)

They cite the condition of the already mentioned match-up effect. An interesting finding among Chinese members of Generation Y (Chan, Ng, Luk, 2013) is the fact that they expect a celebrity to be able to refuse an offer for support of a brand or product that would not fulfill the level of their image, quality and performance. It illustrates differing perceptions of this form of marketing communication among various groups of young people.

Bush, Martin, Bush (2004) discovered in their study that sports celebrities have a strong positive influence among Generation Y in the USA on the positive word-ofmouth communication and brand loyalty. However, the effect on product or brand switching and complaint behavior has not been proved. These authors' study was later repeated by Dix, Phau, Pougnet (2010) who confirmed the positive effects on the word-of-mouth communication and brand loyalty. In the Australian young generation, 
sports celebrities have a significant effect also on brand switching and complaint behavior. The result of these studies shows the expectation that the use of a sports celebrity can influence young consumers when they choose a product, may influence their tendency to speak positively about these brands and may seek recourse for their dissatisfaction with a product directly with the particular brand instead of boycotting it.

\section{RESEARCH AIM}

The main objective of this research is to determine what effect if any the use of sports celebrities in companies' marketing communications as reference groups has on the purchasing preferences of Generation Y.

\section{METHODS}

For the research, the authors selected both quantitative and qualitative methods. For quantitative survey, they used questionnaires. For qualitative research, they used group discussions.

\section{Research question}

Does the use of sports celebrities as opinion leaders in marketing communication have a positive effect on the consumer preferences of members of Generation $\mathrm{Y}$ ?

\section{Research sample}

The basic research sample is formed by part of Prague's population of Generation $\mathrm{Y}$ members. Even despite the definitive lack of a clear definition of this generation, the authors selected, for the purposes of the research, students who attend educational institutions in Prague in person between the ages of 15 and 28. The authors selected the educational institutions with the help of available selections from a preprepared database. Cooperation with the specified educational institutions is used for questioning groups in the 15 to 19 age range (secondary school students) and the 20 to 28 age range (university students). Within these institutions, the authors selected whole classes of respondents (students) using the technique of suitable opportunity (availability). For each selected level of educational institutions, the authors selected three of them (3 secondary schools, 3 universities).

When determining the size of the sample for the questionnaire-based survey, the authors looked at a combination of multiple approaches (Kozel, Mynářová, Svobodová, 2011; Andrew, Pedersen, McEvoy, 2011) and studies conducted with the use of the questionnaire (Bush, Martin, Bush, 2004; Dix, Phau, Pougnet, 2010). The resulting size of the sample for the conducted questionnaire-based survey was 416 respondents.

The selection of respondents for the group discussion is based on the technique of suitable opportunity (or availability). The total number of respondents within the scope of group discussions is 41 , specifically 27 men and 14 women. The structure of the group discussions is derived from the defined operationalization of the problem examined. For basic dimensions, the authors added comments and discussions regarding feelings, stances, opinions, reactions, and changes in buying preferences when sports celebrities were used in companies' marketing communication. 
Table 1 Structure of respondents

\begin{tabular}{l|l|c|c}
\hline \multicolumn{1}{c|}{ Criterion } & \multicolumn{1}{|c|}{ Variants } & Absolute size & Relative size (\%) \\
\hline \multirow{3}{*}{ Gender } & Male & 205 & 49.28 \\
& Female & 211 & 50.72 \\
& Total & 416 & 100 \\
\hline \multirow{5}{*}{ Educational institution } & Secondary school & 280 & 67.31 \\
& University & 136 & 32.69 \\
& Total & 416 & 100 \\
\hline \multirow{3}{*}{ Residence } & Prague & 265 & 63.70 \\
& Outside of Prague & 151 & 36.30 \\
& Total & 416 & 100 \\
\hline
\end{tabular}

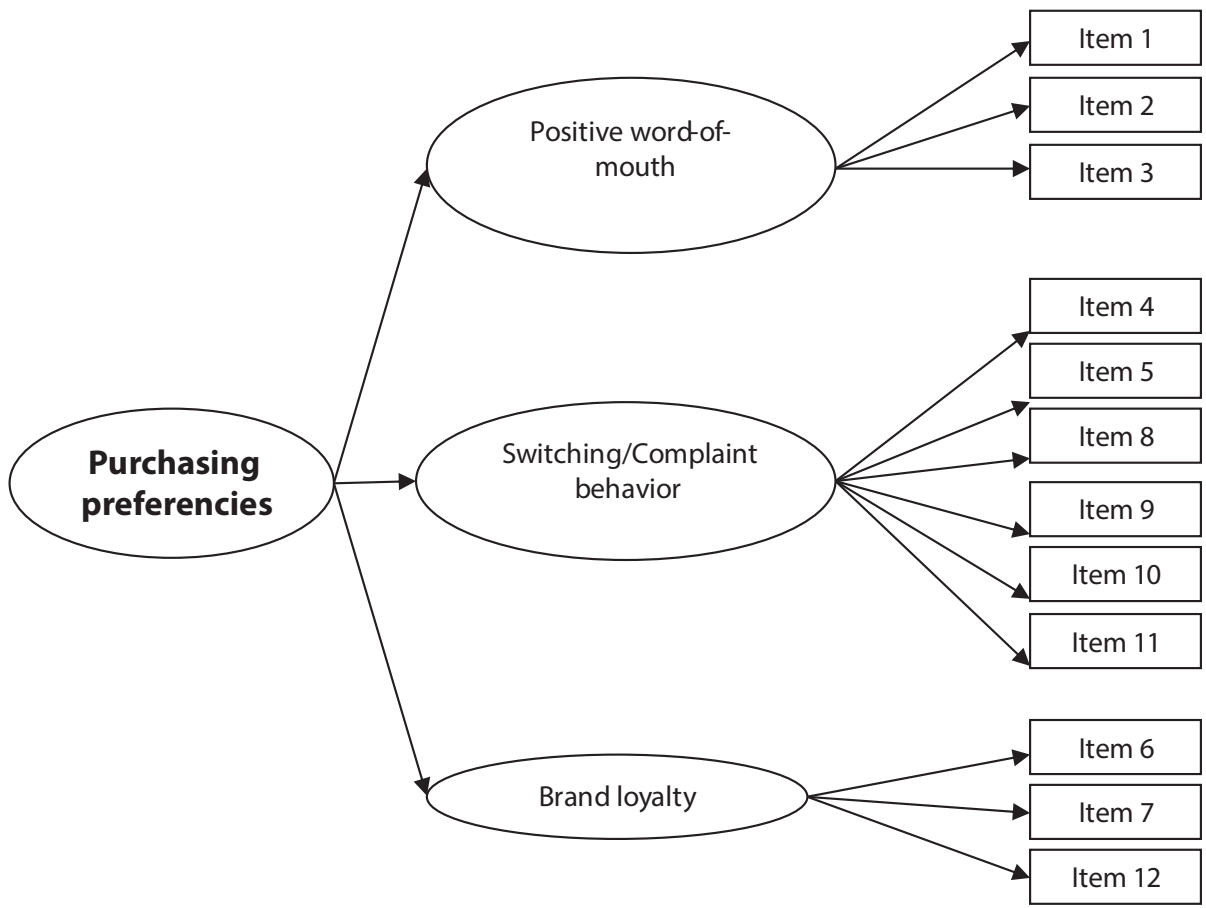

Figure 1 Defined operationalization of the problem examined. Source: Own processing according to Bush, Martin, Bush (2004, p. 112) 


\section{Questionnaire survey}

The used questionnaire contains a series of claims, which respondents evaluate using a 7-point "strongly disagree" to "strongly agree" continuum (Likert scale). The original version of the standardized questionnaire of the specified American research by authors Bush, Martin, Bush (2004) is the sample for the questionnaire. The authors selected the model, since it was used successfully in two research studies that brought relevant results to the examined problem (Bush, Martin, Bush, 2004; Dix, Phau, Pougnet, 2010). For clarity, figure 1 shows the used structural model as the defined operationalization of the problem examined. All items are presented in the Appendix.

Like in the case of the original two research studies on this topic (Bush, Martin, Bush, 2004; Dix, Phau, Pougnet, 2010), the authors used a confirmative approach and, thus, the use of the confirmatory factor analysis. The confirmatory factor analysis here uses the Structural equation modeling (SEM).

The authors tested the model with the help of Mplus in two variants. The first variant shows data of ordinal character to which the use of an evaluation scale corresponds (hereinafter M1). The second variant shows (in view of the details of the evaluation scale) data of a continual (interval-based) character (hereinafter M2). The model has been tested in 3-factor form based on the specified operationalization. Table 2 shows the resulting values of fit indexes of the two tested models, including required values for the model acceptance.

Table 2 Fit indexes

\begin{tabular}{l|c|c|c|c|c|c}
\hline \multicolumn{1}{c|}{ Model } & $\mathbf{X}^{2}$ & Number of degrees of freedom & CFI & TLI & RMSEA & WRMR/SRMR \\
\hline M1 & 770.336 & 51 & 0.841 & 0.794 & 0.184 & 2.126 \\
$M 2$ & 501.749 & 51 & 0.750 & 0.676 & 0.146 & 0.094 \\
\hline FIT-ord. & \multicolumn{2}{|c|}{ as small as possible with the highest as } & $>0.95$ & $>0.95$ & $<0.08$ & $<1$ \\
FIT-int. & \multicolumn{2}{|c|}{ possible number of degrees of freedom } & $>0.95$ & $>0.95$ & $<0.08$ & $<0.05$ \\
\hline
\end{tabular}

The specified values of the fit indexes indicate the inability to accept the used model in the form in which it is tested. Even though the value of the Chi-squared using M2 has decreased, not one of the fit indexes reaches the required values specified in table 2. For M2, although the values of the indexes are closer to the required values, and this seems to be more advantageous, it is still not possible to consider the used model to be a well fitting one. During closer examination of the results of the structural equation modeling, the authors assessed the standardized parameter estimates of individual items in view of the measured dimensions of the model. These standardized parameter estimates are specified in table 3. 
Table 3 Standardized parameter estimates of individual items

\begin{tabular}{l|c|c|c|c|c|c}
\hline \multirow{2}{*}{ Item } & \multicolumn{3}{|c|}{ Factor-M1 } & \multicolumn{3}{c}{ Factor - M2 } \\
\cline { 2 - 7 } & W0M & SWITCH/COMP & LOYA & W0M & SWITCH/COMP & LOYA \\
\hline Item 1 & 0.847 & & & 0.824 & & \\
Item 2 & 0.846 & & & 0.828 & & \\
Item 3 & 0.791 & & & 0.699 & & \\
Item 4 & & 0.864 & & & 0.718 & \\
Item 5 & & 0.114 & & & 0.056 & \\
Item 6 & & & 0.798 & & & 0.736 \\
Item 7 & & & 0.775 & & & 0.684 \\
Item 8 & & 0.231 & & & 0.144 & \\
Item 9 & & 0.444 & & & 0.316 & \\
Item 10 & & 0.590 & & & 0.437 & \\
Item 11 & & 0.436 & & & 0.332 & \\
Item 12 & & & 0.764 & & & 0.700 \\
\hline
\end{tabular}

During assessment of standardized parameter estimates, it is apparent that the dimensions of positive $\mathrm{W}-\mathrm{O}-\mathrm{M}$ and brand loyalty are adequately measured by the selected indicators. The standardized parameter estimates range from 0.764 to 0.847 for $\mathrm{M} 1$ and from 0.684 to 0.828 for M2. These particular items significantly indicate latent factors based on the model used. In this respect, the SWITCH/COMP dimension is significantly problematic. Items 5 and 8 report very weak standardized parameter estimates for both variants of the model. Items 9,10 and 11 report medium strong standardized parameter estimates and only item 4 strongly measures the particular latent factor. It is just this dissimilarity which indicates insufficiency in measuring the model's fit. Table 4 also shows the standardized parameter estimates during analysis of a higher level, both for M1 and M2. It is apparent from the values that the SWITCH/ COMP dimension reports major differences in values between the measured models.

Table 4 Standardized parameter estimates of model dimensions

\begin{tabular}{l|c|c|c}
\hline \multicolumn{4}{c}{ Model M1 } \\
\hline W0M & Purchasing preferences & W0M & SWITCH/COMP \\
\hline SWITCH/COMP & 0.94 & & \\
\hline LOYA & 0.76 & 0.72 & 0.72 \\
\hline \multicolumn{4}{|c|}{ Model M2 } \\
\hline WOM & 0.95 & 0.89 & SWITCH/COMP \\
\hline SWITCH/COMP & Purchasing preferences & W0M & \\
\hline LOYA & 0.9 & 0.74 & 0.79 \\
\hline
\end{tabular}




\section{RESULTS}

\section{Positive word-of-mouth}

The results show that the use of sports celebrities in marketing communication has a small effect on the examined sample. Respondents do not have a tendency to spread or disclose information or to talk with others about products or brands that are supported by sports celebrities.

Like in the case of item 1, item 2 also indicates that the effect of sports celebrity endorsements is small, at least according to the specified results. Therefore, it can be expected that if anyone asks for assistance, advice or a recommendation for a brand or product from a member of Generation $Y$ that member will not primarily recommend products or brands that are endorsed by sports celebrities. In addition, that Generation Y member when making recommendations will prioritize and take into consideration other aspects (such as experience, price, quality, etc.) rather than sports celebrity endorsement.

Persuasion within mutual communication between the member of Generation $Y$ and his/her other relatives or friends is not common for the examined sample, as far as products or brands endorsed by sports celebrities are concerned. The persuasion function therefore remains in companies' own communication tools and elements.

It is apparent from group discussions that, in the case of spontaneous communication between members of Generation Y, the use of sports celebrities in marketing communication of companies does not have a significant effect. In a situation when respondents are asked for advice from someone during selection of a product or brand, the respondents positively orient themselves according to their own experience and satisfaction with the particular product or brand. Whether or not the product is endorsed by a sports celebrity is unimportant. However, six respondents across all of the discussion groups admit the influence of sports celebrities in the case of these athletes' own brands. As far as persuasion of other individuals is concerned, respondents positively reject any effect of a sports celebrity endorsement. Persuasion then always depends on the recommender's own satisfaction with a product or brand.

\section{Switching/Complaint Behavior}

The use of sports celebrities in marketing does not dissuade respondents too much from purchasing other companies' products or brands. A total of $63.94 \%$ of respondents provided disagreeing responses to this statement as compared to only $19.48 \%$ who provided agreeing responses to it; the remaining respondents were neutral in their responses. This means that only every fifth respondent admits the influence of sports celebrity endorsement in refusing to purchase a product from a different company without such celebrity support.

Item 5 reveals the potential fundamental factor influencing purchasing preferences of the young generation of consumers. That factor is the price. The most responses were neutral (23.80\%). $44.23 \%$ of respondents provided one of the agreeing response variants, while only $31.98 \%$ gave disagreeing responses. The variability of responses is quite considerable; that is why no clear conclusion can be deduced from these results.

A total of $46.16 \%$ of respondents said they agreed with the presented claim that if dissatisfied with a product of a particular brand they would switch to the competition 
regardless of whether or not the original product or brand is endorsed by a sports celebrity. However, the percentage of respondents who said that even despite dissatisfaction they would not switch to a competing brand, $37.02 \%$, is not insignificant. It shows lucrative potential for companies using sports celebrities.

The Generation Y members addressed in the survey do not have a tendency to dissuade other customers if they are dissatisfied from a brand endorsed by a sports celebrity. The fact that social media nowadays enable these individuals to communicate quickly and to a large audience would otherwise represent a major threat of loss of customers.

Most of the respondents regarded as a last resort the option of contacting an external institution involved in consumer protection, business inspection authorities, etc. in the event of dissatisfaction with a product or brand. The results reflect this. Only $9.62 \%$ of respondents said they were more or less likely to contact one of these institutions.

Whether, in the case of dissatisfaction with a product or brand, respondents would contact the company itself or its employees, is a desirable response from a customer for companies. This gives the company feedback with which it can continue to work and strive to increase customer satisfaction with a product. It cannot be clearly stated whether this would be significantly aided by a sports celebrity endorsement, as the results show. A total of $56.97 \%$ of respondents gave a response in the disagreeing range of the evaluation scale. On the contrary, $28.85 \%$ gave an agreeing response, and although that is not an insignificant amount of respondents, there is still an apparent disagreeing tendency of responses. For companies using sports celebrities in marketing, the results indicate that in this case a certain effect can be achieved at least among some of the individual members of Generation Y addressed in the survey. Each piece of feedback from a customer brings valuable information for the company and will help it with constant improvement of the quality of its products as well as customer satisfaction.

Like in the questionnaire-based survey, in the group discussions as well, the price seems to be a more important factor than a sports celebrity endorsement. Respondents from a secondary school (discussion groups 1 and 2) also mention major limits in their purchasing expenditure and budget. Therefore, they would prefer to choose a less expensive product with comparable quality. It has also been shown that a sports celebrity endorsement itself gives an impression of a certain level of product quality. It is just this expected product quality combined with the price that creates a decisive element during selection of a particular brand of product.

In the case of respondents' dissatisfaction with a product of a certain brand, reactions in purchasing behavior are quite varied; however, they lead to switching to a competitor's brand in most instances. Feedback given directly to employees of a particular company is not exploited, except for standard complaints. Contacting institutions involved in consumer defense and protection, business inspection authorities, etc. is not exploited either. Overall, the respondents exclude the effect of a sports celebrity endorsement on a change of exploited responses when expressing dissatisfaction with a product or brand. 


\section{Brand Loyalty}

The results show that the price is a very important factor for respondents. A total of $66.34 \%$ of respondents gave a response in the disagreeing range of the evaluation scale. This means that the effect of the exploitation of a sports celebrity for support of a brand or product is less significant than focus on the price of a product for nearly two thirds of individuals from the research sample. The increase in price is compensated by a sports celebrity endorsement for $18.03 \%$ of respondents only. The importance of the price for respondents corresponds to the typical price sensitivity of a Czech consumer. For individuals from Generation Y, it can be assumed that this characteristic will not change significantly, at least based on the information obtained from the responses. The use of sports celebrities for marketing support in this case is effective if it does not in any way significantly increase the price of a product compared to the competition. A famous athlete will then represent added value and a competitive advantage for the company.

However, it is necessary to point out the fact that for $19.71 \%$ of respondents, a famous sports celebrity endorser represents a significant added value, which will retain the particular customer with a brand even despite less expensive competition. Sports celebrities used in marketing therefore do not have a major effect within the sample of respondents on greater brand loyalty; however, the opposite is true for a part of them.

A total of $42.79 \%$ of respondents said they would not be motivated by a sports celebrity's endorsement to buy a certain brand. However, $37.02 \%$ of respondents admit that such an effect would have influenced them. The remaining $20.19 \%$ gave a neutral response (value 4), which was also the most frequent value.

Table 5 Conducted and original research averages comparison

\begin{tabular}{l|c|c|c|c}
\hline \multirow{2}{*}{ Item } & \multicolumn{2}{|c|}{$\begin{array}{c}\text { Research } \\
\mathbf{n}=\mathbf{4 1 6}\end{array}$} & $\begin{array}{c}\text { Bush, Martin, Bush (2004) } \\
\mathbf{n}=\mathbf{2 1 8}\end{array}$ \\
\cline { 2 - 5 } & Men & Women & $\mathrm{n}=118$ & Women \\
& $\mathrm{n}=\mathbf{2 0 5}$ & 3.1659 & 3.96 & 4.81 \\
\hline Item 1 & 3.3951 & 3.0853 & 3.80 & 4.59 \\
Item 2 & 3.4439 & 2.3270 & 3.26 & 5.07 \\
Item 3 & 2.6732 & 3.0379 & 3.53 & 3.45 \\
Item 4 & 2.9902 & 4.2654 & 3.73 & 3.64 \\
Item 5 & 4.0634 & 2.7536 & 3.45 & 3.63 \\
Item 6 & 3.0878 & 2.4502 & 3.18 & 3.45 \\
Item 7 & 2.9366 & 4.0900 & 3.56 & 3.69 \\
Item 8 & 4.1854 & 3.1327 & 3.20 & 3.29 \\
Item 9 & 3.2878 & 1.9573 & 3.19 & 3.15 \\
Item 10 & 2.1073 & 3.1706 & 3.33 & 3.42 \\
Item 11 & 3.4293 & 3.6825 & 4.02 & 4.75 \\
\hline Item 12 & 3.9561 & &
\end{tabular}


It is apparent from the group discussions that within the scope of brand loyalty, respondents agree on the primary influence of a combination of price and satisfaction with a product or brand. A sports celebrity endorsement is only an added value for them but does not have as much of an effect as the specified satisfaction/price combination. Nonetheless, at least when a particular type of product is first purchased, there is a willingness to pay a higher price for a product promoted and presented by a sports celebrity among 18 of the 41 total respondents across all discussion groups.

\section{Other effects}

Within the scope of other effects, the respondents state that the use of a sports celebrity endorsement significantly increases the attractiveness of a used communication message particularly in tools such as advertising and PR. Communication messages are conveyed by a known real celebrity with sports success, rather than an anonymous actor or individual only. Such marketing communication can be decisive during selection of a product when a first purchase is made.

Another factor that respondents perceive when using a sports celebrity endorsement is the consideration of whether the particular sports celebrity has anything to do with the supported product or brand. In this case, the respondents thus assess the match-up effect, as mentioned in the theoretical part of this work.

The results of group discussions to a great extent are confirmed by the data obtained from the questionnaire-based surveys, despite the results from the confirmatory factor analysis of the Bush-Martin-Bush model used.

\section{DISCUSSION AND IMPLICATIONS}

For the questionnaire survey as a diagnostic tool, the authors used a questionnaire which originated from studies of authors Bush, Martin, Bush (2004) and Dix, Phau, Pougnet (2010). Both original studies proved good usability of the questionnaire, particularly with respect to a quality structural model. In their case, the fit indexes of the measured models reported values representing good fit models. The model of purchasing preferences contains three dimensions: positive word-of-mouth; brand/ product switching and complaint behavior; brand loyalty.

Testing of the structural model in our case points to unsatisfactory values of fit indexes of both variants of models: ordinal data and the considered interval data. During detailed examination, items 5 and 8 seem the most problematic. The authors refuse exclusion of these items, due to the need to maintain content validity of the questionnaire. For any future research, it will therefore be necessary to reformulate the claims and, if need be, to reverse the significance of the evaluation scale so that the agreeing part supports the positive effect of exploiting sport celebrities for a given reaction. In the original research (Bush, Martin, Bush, 2004), there are no problematic items, and the standardized parameter estimates of all items range from 0.75 to 0.93 . Within the scope of this research, the standardized parameter estimates range from 0.114 to 0.864 (in the case of ordinal data) and 0.056 to 0.828 (in the case of interval data). The values of standardized parameter estimates are then fully reflected in the values of fit model indexes. 
For further use of the questionnaire, it is necessary to make major changes to the structural model itself, particularly to the dimensions related to the brand/product switching and complaint behavior. It seems to make more sense from the authors' point of view to use the original Zeithaml-Berry-Parasuraman model (Zeithaml, Berry, Parasuraman, 1996), or eventual use of the modified five-dimensional Zeithaml-Berry-Parasuraman model (Zeithaml, Berry, Parasuraman, 1996).

The specified results from the questionnaire-based surveys cannot be considered representative, since the selection of respondents is realized based on the principle of availability. Therefore, it does not involve a representative technique for selection of respondents. Even so, the results bring valuable information about marketing communication and its tools, such as sports celebrity endorsement. The sample of the questionnaire-based survey contains 416 respondents, which is a satisfactory number for marketing research.

The results and interpretation of data from questionnaire surveys indicate that, compared to research conducted in the USA (Bush, Martin, Bush, 2004) and Australia (Dix, Phau, Pougnet, 2010), the sample of respondents from Prague's secondary schools and universities differs. Therefore, the results do not support the examined effect. A large number of respondents reject the effect of sports celebrities in marketing communication of companies on their purchasing preferences, namely for all three dimensions. However, the American respondents admit and confirm the examined effect of positive word-of-mouth and brand loyalty. The Australian respondents confirm the effect also in relation to the brand/product switching and complaint behavior. Both studies show that purchasing preferences of women from Generation $\mathrm{Y}$ are more influenced by the effect of using sports celebrities than those of men. However, this research also shows a tendency for women to be even less influenced by the examined effect than men.

So the quantitative part of the research supports authors Alnawas (2010), Koernig, Boyd (2009), Lafferty, Goldsmith (1999) but on the contrary does not agree with the results of studies by authors Bush, Martin, Bush (2004), Dix, Phau, Pougnet (2010), Shuart (2007), Pringle (2004), Kaser, Oelkers (2005). In particular, there is an interesting conflict with real case studies to which an entire publication by author Pringle (2004) is devoted and further with many other Internet sources monitoring the market environment of sports, such as SportsRevolution (online, 2016), Yutang Sports (online, 2015), SportTechie (online, 2016), SportBiz (online, 2011-2014), and the general marketing environment (including sports), such as Forbes (online, 2016), Marketing Week (online, 2016), The Drum (online, 2016), etc. Companies are investing large amounts into cooperation with sports celebrities. This will clearly bring about certain benefits for companies from the sale of products.

However, group discussions bring additional results, though without the ability to generalize in relation to the entire basic sample. Groups are selected based on their availability and include a total of 41 respondents representing the qualitative part of the research. The combination of the brand/product with a sports celebrity is seen as a guarantee of product quality, which is confirmed by author Č́slavová (2009). Other respondents state preferences supported by the brand during the first purchase of the product and its first try out, even despite the higher price of such product. A similar effect is described by authors Chan, $\mathrm{Ng}$, Luk (2013) in their study. 
The respondents in group discussions also mention other effects, which are not directly related to purchasing preferences but which can also influence them indirectly. The clear increase in the attractiveness of the communication message, which can increase the tendency to buy a endorsed product when a first purchase is made, is one such effects. Increasing of the attractiveness of the communication message is specified mainly by authors Martin (1996), Sliburyte (2009) and Ranjbarian, Shekarchizade, Momeni (2010). The perception of the match-up effect, when respondents assess whether a sports celebrity has anything to do with the particular product besides just marketing endorsement, is the second mentioned effect. This effect is pointed out by authors Alnawas (2010) and Sliburyte (2009). At the conclusion of the discussion, it is necessary to answer the defined research question:

Does the use of sports celebrities as opinion leaders in marketing communication have a positive effect on the consumer preferences of members of Generation Y in Prague?

Based on the results of quantitative and qualitative parts of the research, it can be stated that for positive word-of-mouth the use of sports celebrities in marketing communication does not have the desired positive (or even a negative) effect. A relevant effect is also neither demonstrated nor proven in relation to the brand/product switching and complaint behavior.

Brand loyalty of approximately $20 \%$ of respondents in the questionnaire-based survey is influenced by the examined effect. The group discussions then show that marketing endorsement by a sports celebrity is used or perceived particularly for quality products with a greater likelihood of customer satisfaction and subsequent brand loyalty. Furthermore, a sports celebrity can support a tendency to try out a product or for a first purchase thanks to awareness and attractiveness of the communicated message. The first purchase or try-out in combination with satisfaction with the perceived quality of a product can lead to customer loyalty. Therefore, the examined effect can be confirmed but it is just indirect.

\section{CONCLUSION}

The use of sports celebrities in marketing communication of companies nowadays is already the standard tool of many brands from the most prestigious and most valuable to less valuable ones. Companies invest large sums of money into cooperation with famous and successful sports celebrities. The practical use of the discovered findings can be in the form of base materials for creation of a communication strategy of companies whose target group (or one of whose target groups) is Generation Y. Use of sports celebrities in marketing communication is often a very expensive business. The effects stemming from such cooperation can be summarized based on the results of research as follows:

- increased awareness of a product/brand,

- increased attractiveness of a communicated message,

- increased awareness of a communicated message,

- support for trying out a product/brand,

- support during an initial purchase of a product/brand,

- an indirect increase in brand loyalty, assuming that there is adequate product quality,

- reduction of price sensitivity during the first purchase or try-out of a product. 
If companies have these effects as the goals of their marketing communication and have enough funds to invest in a suited sports celebrity, then it is an effective tool. However, the combination of the price and perceived quality or satisfaction with the product still remains in first place. If this is supplemented by an attractive marketing communication embodying a well known sports celebrity, it becomes an important competitive advantage in the current highly competitive market environment.

\section{ACKNOWLEDGEMENTS}

This work was supported by the scientific branch development program PROGRESS [Q19] at the Charles University in Prague.

\section{REFERENCES}

Agrawal, J., \& Kamakura, W. A. (1995). The economic worth of celebrity endorsers: an event study analysis. Journal of Marketing, 59(3), 56-62.

Alnawas, I. A. M. (2010). The Influence of Using Celebrities on Consumers Buying Behavior. Interdisciplinary Journal of Contemporary Research in Business, 2(1), 257-282.

Andrew, D. P. S., Pedersen, P. M., \& McEvoy, Ch. D. (2011). Research Methods and Design in Sport Management. Champaign, IL: Human Kinetics.

Bearden, W. O., \& Etzel, M. J. (1982). Reference Group Influence on Product and Brand Purchase Decisions. Journal of Consumer Research, 9(2), 183-194.

Bhatt, N., Jayswal, R. M., \& Patel, J. D. (2013). Impact of Celebrity Endorser's Source Credibility on Attitude Towards Advertisements and Brands. South Asian Journal of Management, 20(4), 74-95.

Bush, A. J., Martin, C. A., \& Bush, V. D. (2004). Sports Celebrity Influence on the Behavioral Intentions of Generation Y. Journal of Advertising Research, 44(1), 108-118.

Carroll, A. (2009). Brand communications in fashion categories using celebrity endorsement. Journal of Brand Management, 17(2), 146-158.

Čáslavová, E. (2009). Management a marketing sportu. [Management and Marketing of Sport. In Czech.] Prague: Olympia.

Čáslavová, E., \& Višněvský, A. (2016). Identification of Ice Hockey world Championship International sport Event through Brand personality. In: Conference proceeding World Academy of science, engineering and technology, Amsterdam The Netherlands Aug. 04-05, 18(8), 8-15.

Chan, K., Ng, Y. L., \& Luk, E. K. (2013). Impact of celebrity endorsement in advertising on brand image among Chinese adolescents. Young Consumers, 14(2), 167-179.

Choi, S. M., \& Rifon, N. J. (2007). Who Is the Celebrity in Advertising? Understanding Dimensions of Celebrity Images. The Journal of Popular Culture, 40(2), 304-324.

Chuang, S. Ch., Cheng, Y. H., \& Hsu, Ch. T. (2012). The influence of suggestions of reference groups in the compromise effect. Journal of Economic Psychology, 33(3), 554-565.

Clark, R. C., \& Horstmann, I. J. (2013). A model of advertising format competition: on the use of celebrities in ads. Canadian Journal of Economics, 46(4), 1606-1630.

Darley, W. K., Blankson, Ch., \& Luethge, D. J. (2010). Toward an Integrated Framework for Online Consumer Behavior and Decision Making Process: A Review. Psychology \& Marketing, 27(2), 94-116.

Dix, S., Phau, I., \& Pougnet, S. (2010). Bend it like Beckham: the influence of sports celebrities on young adult consumers. Young Consumers, 11(1), 36-46.

Elberse, A., \& Verleun, J. (2012). The Economic Value of Celebrity Endorsement. Journal of Advertising Research, 52(2), 149-165. 
Erasmus, A. C., Boshoff, E., \& Rousseau, G. G. (2001). Consumer decision-making models within the discipline of consumer science: a critical approach. Journal of Family Ecology and Consumer Sciences, 29(1), 82-90.

Escalas, J. E., \& Bettman, J. R. (2003). You Are What They Eat: The Influence of Reference Groups on Consumers' Connection to Brands. Journal of Consumer Psychology, 13(3), $339-348$.

Forbes (2016). Available at: http://www.forbes.com (accessed July 26, 2016).

Jacoby, J. (2002). Stimulus-Organism-Response Reconsidered: An Evolutionary Step in Modeling (Consumer) Behavior. Journal of Consumer Psychology, 12(1), 51-57.

Kaser, K., \& Oelkers, D. B. (2005). Sports and Entertainment Marketing. USA: South-Western, Thomson.

Keel, A., \& Nataraajan, R. (2012). Celebrity Endorsements and Beyond: New Avenues for Celebrity Branding. Psychology and Marketing, 29(9), 690-703.

Koernig, S. K., \& Boyd, T. C. (2009). To Catch a Tiger or Let Him Go: The Match-up Effect and Athlete Endorsers for Sport and Non-Sport Brands. Sport Marketing Quarterly, 18(1), 25-37.

Kotler, P., et al. (2007). Moderní marketing - 4. evropské vydání. [Modern Marketing - 4th European Edition. In Czech.] Prague: Grada Publishing.

Kotler, P., \& Keller, K. L. (2007). Marketing management - 12th Edition. Prague: Grada Publishing.

Koudelka, J. (1997). Spotrební chování a marketing. [Consumer Behavior and Marketing. In Czech.] Prague: Grada Publishing.

Koudelka, J. (2006). Spotřební chování a segmentace trhu. [Consumer Behavior and Market Segmentation. In Czech.] Prague: VSEM.

Kozel, R., Mynářová, L., \& Svobodová, H. (2011). Moderní metody a techniky marketingového výzkumu. [Modern methods and techniques of marketing research. In Czech.] Prague: Grada Publishing.

Lafferty, B. A., \& Goldsmith, R. E. (1999). Corporate Credibility's Role in Consumers' Attitudes and Purchase Intentions When a High versus a Low Credibility Endorser Is Used in the Ad. Journal of Business Research, 44(2), 109-116.

Lagae, W. (2005). Sports Sponsorship and Marketing Communications - A European Perspective. England: Pearson Education Limited.

Lear, K. E., Runyan, R. C., \& Whitaker, W. H. (2009). Sports celebrity endorsements in retail products advertising. International Journal of Retail \& Distribution Management, 37(4), 308-321.

Lim, G. (2005). Idol to Icon: The creation of celebrity brands. Singapore: Marshall Cavendish Business.

Marketing Week (2016). Available at: https:/ /www.marketingweek.com (accessed July 26, 2016).

Martin, J. H. (1996). Is the athlete's sport important when picking an athlete to endorse a nonsport product? The Journal of Consumer Marketing, 13(6), 28-43.

Martin, N., \& Morich, K. (2011). Unconscious mental processes in consumer choice: Toward a new model of consumer behavior. Journal of Brand Management, 18(7), 483-505.

Masood, A. (2011). Celebrity endorsement affecting consumer's attitude towards the Ads. Saarbrücken: LAP LAMBERT Academic Publishing GmbH \& Co. KG.

McCarthy, E. J., \& Perreault, W. D. (1993). Basic marketing: a global managerial approach. USA: Richard D. Irwin, Inc.

Miller, F. M., \& Laczniak, G. R. (2011). The Ethics of Celebrity-Athlete Endorsement: What Happens When a Star Steps Out of Bounds? Journal of Advertising Research, 51(3), 499-510. 
Morton, L. P. (2002). Targeting Generation Y. Public Relations Quarterly, 47(2), 46-48.

Nicholson, M. (2007). Sport and the Media: Managing the Nexus. Oxford, UK: Elsevier.

Park, W. C., \& Lessig, P. V. (1977). Students and Housewives: Differences in Susceptibility to

Reference Group Influence. Journal of Consumer Research, 4(2), 102-110.

Pringle, H. (2004). Celebrity Sells. West Sussex, UK: John Wiley \& Sons.

Puiu, C. (2008). Consideration about Group Influences on Consumer Behavior. The Annals of the University of Oradea - Economic Sciences, 17(4), 1136-1139.

Ranjbarian, B., Shekarchizade, Z., \& Momeni, Z. (2010). Celebrity Endorser Influence on Attitude Toward Advertisements and Brands. European Journal of Social Sciences, 13(3), 399-407.

Schiffman, L. G., \& Kanuk, L. L. (2004). Nákupní chování. [Consumer Behavior. In Czech.] Brno: Computer Press.

Schlossberg, H. (1996). Sports Marketing, Oxford, UK: Blackwell Publishers.

Seno, D., \& Lukas, B. A. (2007). The equity effect of product endorsement by celebrities: A conceptual framework from a co-branding perspective. European Journal of Marketing, $41(1 / 2), 121-134$.

Shuart, J. (2007). Heroes in sport: assessing celebrity endorser effectiveness. International Journal of Sports Marketing \& Sponsorship, 8(2), 126-140.

Simmers, Ch. S., Damron-Martinez, D., \& Haytko, D. L. (2009). Examining the Effectiveness of Athlete Celebrity Endorser Characteristics and Product Brand Type: The Endorser Sexpertise Continuum. Journal of Sport Administration \& Supervision, 1(1), 52-64.

Sliburyte, L. (2009). How celebrities can be used in advertising to the best advantage? World Academy of Science, Engineering and Technology, International Science Index 34, International Journal of Social, Behavioral, Educational, Economic and Management Engineering, 3(10), 934-939.

SportBiz (2011-2014). Available at: http://www.sportbiz.cz.

SportsRevolution (2016). Available at: http://www.sportsrevolution.co.uk.

SportTechie - Sports Technology News (2016). Available at: http:/ /www.sporttechie .com.

Spry, A., Pappu, R., \& Cornwell, B. T. (2011). Celebrity endorsement, brand credibility and brand equity. European Journal of Marketing, 45(6), 882-909.

Stafford, J. E. (1966). Effects of Group Influences on Consumer Brand Preferences. Journal of Marketing Research, 3(1), 68-75.

Stevens, J. A., Lathrop, A. H., \& Bradish, Ch. L. (2003). Who is Your Hero? Implications for Athlete Endorsement Strategies. Sport Marketing Quarterly, 12(2), 103-110.

Temporal, P. (2010). Advanced Brand Management: Managing Brands in a Changing World. Singapore: John Wiley \& Sons (Asia).

The Drum US - Marketing, advertising, design and digital news (2016). Available at: http:// www.thedrum.com.

Tomek, G., \& Vávrová, V. (2008). Marketing od myšlenky k realizaci. [Marketing from idea to realization. In Czech.] Prague: Professional Publishing.

Van Den Bergh, J., \& Behrer, M. (2012). Jak cool značky ziustávají hot: Marketing zaměřený na mladou ,generaci $Y^{\prime}$. [How cool brands stay hot: Marketing focused on the young "generation Y”. In Czech.] Brno: BizBooks.

Vysekalová, J., et al. (2011). Chování zákazníka: Jak odkrýt tajemství „černé skř́ňky“. [Customer behavior: How to uncover the mystery of the "black box". In Czech.] Prague: Grada Publishing.

Yang, J., He, X., \& Lee, H. (2007). Social reference group influence on mobile phone purchasing behaviour: a cross-nation comparative study. International Journal of Mobile Communications, 5(3), 319-338. 
Yutang Sports - The Premier Sports Marketing Platform in China (2015). Available at: http:// en.ytsports.cn (accessed July 26, 2016).

Zeithaml, V. A., Berry, L. L., \& Parasuraman, A. (1996). The Behavioural Consequences of Service Quality. Journal of Marketing, 60(2), 31-46. 